\title{
RESTITUTIO. ADUCEREA ÎN ŢARĂ A COPIEI COLUMNEI LUI TRAIAN. UN INTERVIU CU CORNEL BURTICĂ, FOST AMBASADOR AL ROMÂNIEI LA ROMA
}

MARIANA CONOVICI, GEORGE TROHANI

RESTITUTIO. L'ARRIVÉE EN ROUMANIE DE LA COPIE DE LA COLONNE DE TRAJAN.

UNE INTERVIEW AVEC CORNEL BURTICĂ, ANCIEN AMBASSADEUR DE ROUMANIE À ROME

Il s'agit d'une interview avec l'ancien ambassadeur de Roumanie à Rome, pendant les années 19661969, concernant histoire de la récupération du moulage de la Colonne de Trajan et de l'Accademia di Romania de Rome par le gouvernement roumain avec l'aide du Vatican. L'interview date du 15 juin 2006.

MOTS CLEFS : Colonne de Trajan, Accademia di Romania, Vatican

CUVINTE CHEIE: Columna lui Traian, Accademia di Romania, Vatican

Columna lui Traian a fost mereu în atenția istoricilor de pretutindeni, iar efectuarea de copii ale sale ce pot fi studiate, mai de aproape, de cei interesaţi, a constituit de-a lungul vremurilor o preocupare în special a şefilor de stat deoarece costurile nu erau mici. Şi, cum la Muzeul Naţional de Istorie a României din București se află cea mai fidelă copie, executată în anii 1939-1943, la Roma, subiectul a fost tratat de multe ori. Mai puţin cunoscute sunt însă culisele aducerii acestei copii în ţară, în anul 1967. De aceea, în anul 2006, în ziua de 15 iunie, autorii au realizat un interviu cu Cornel Burtică ${ }^{1}$, fost ambasador al României la Roma în perioada 1966-1969, direct implicat în demersul aducerii copiei Columnei lui Traian la Bucureşti.

Acest interviu a fost publicat în revista Universul Radio, nr. 89, din 27 iulie 2006, care are însă un circuit de difuzare redus. De aceea considerăm utilă republicarea sa, spre folosul celor interesaţi, în prezentul periodic. Dorim să facem menţiunea că în Arhiva Radioului caseta cu înregistrarea are nr. C/CD 1750, respectiv numărul de inventar 3427. Transcrierea dactilografiată i se datorează Marianei Conovici.

De asemenea, dorim să menţionăm faptul că punctele de suspensie (...), din cuprinsul dactilografiat al interviului, reprezintă, în majoritatea cazurilor, pauze mai lungi de respiraţie şi gândire în vorbirea celui intervievat.

Prin urmare, iată desfăşurarea interviului:

Mariana Conovici: O temă foarte interesantă, şi anume aducerea copiei Columnei lui Traian. L-aş ruga pe colegul nostru George Trohani să facă un scurt istoric al copiilor care s-au mai făcut de-a lungul anilor după Columnă.

George Trohani: Cum se ştie, Columna a fost inaugurată în Forul lui Traian la Roma pe 12 mai 113. Ea glorifică războaiele dintre romani şi daci. În decursul vremii s-au făcut mai multe copii după Columnă. Mai întâi François I de Valois, regele Franţei, în 1541, apoi Ludovic al XIVlea, pe la 1700, Napoleon al III-lea, in 1861, au comandat şi s-au executat copii, ultima fiind din aramă galvano-plastică. Apoi regina Victoria a Marii Britanii (a comandat) o copie care şi astăzi se păstrează la Londra. Şi, normal, Vaticanul a avut şi el o copie care se păstra la Muzeul San Giovanni din Laterano.

În 1934 Papa Pius al XI-lea comandă Direcţiei Generale a Muzeelor Vaticanului o nouă copie din beton armat. Acum intervenim şi noi prin Emil Panaitescu², care era directorul Şcolii

\footnotetext{
${ }^{1}$ Cornel Burtică (3 septembrie 1931, județul interbelic Mehedinți - 11 iunie 2013) - om politic român, membru al Consiliului Politic Executiv al PCR, ambasador al Republicii Socialiste România în Italia, Maroc și Malta până în anul 1969, când a fost numit Ministru al Comerțului Exterior.

${ }^{2}$ Emil Panaitescu (11 februarie 1885, Cudalbi, județul Covurlui, astăzi județul Galați - 20 februarie 1958, Roma) istoric, profesor de istorie antică la Facultatea de Litere și Filosofie a Universității dỉ Cluj, director al Institutului de Studii Clasice și al Muzeului de Arheologie din Cluj, fost elev al Școlii Române din Roma și director al acesteia între anii 1929-1940. A se vedea şi I. Opriş, Istoricul Emil Panaitescu şi Şcoala Română de la Roma, Bucureşti, 2014.
} 
Române din Roma. El obţine, în decursul mai multor ani, din 1934 până în 1939, aprobarea forurilor competente de la noi din ţară pentru realizarea unei astfel de copii, idee care la noi exista incă din secolul al XIX-lea.

MC: Domnule (Cornel) Burtică, în 1966 eraţi ambasador al României la Roma. Cât ştiaţi, ce ştiaţi despre această copie a Columnei?

Cornel Burtică: Inainte de a pleca la Roma ca ambasador am fost, cum era obiceiul şi probabil că este şi astăzi, primit de şeful statului. În afară de idei generale privind activitatea mea, Nicolae Ceauşsescu mi-a dat două însărcinări punctuale: una, să obţin retrocedarea copiei Columnei lui Traian care se găsea în depozitele Vaticanului şi, al doilea subiect, era retrocedarea sau recuperarea, mai bine zis, a Accademiei di Romania ${ }^{3}$, care se găsea în custodia statului italian.

În legătură cu Columna ... Această copie a Columnei avea ca scop studiul de către studenţi şi specialişti în domeniul istoriei şi arheologiei. De aceea era făcută ca o copie desfăşurată pe orizontală şi nu pe verticală. A fost plătită de Statul Român. Al Doilea Război Mondial a făcut ca ea să nu poată fi transportată în ţară în vremea respectivă, iar în 1950, din păcate, s-au întrerupt relaţiile dintre România şi Vatican. Vaticanul a depozitat copia la Museo Laterano şi Palazzo delle Mostre. Trebuie să vă spun că această copie a fost făcută din fragmente, desfăşurată pe orizontală cum spuneam, dar din fragmente ... o mulţime, pentru că atunci când le-am trimis eu în ţară, îmi amintesc, am ambalat-o şi am transportat-o cu 18 vagoane de marfă. Documentele care atestau comanda şi plăţile se găseau la secretarul Accademiei di Romania, Emil Panaitescu care între timp decedase, iar soţia sa $a^{4}$ nu a vrut sub nici o formă să ne dea documentele. Ei ceruseră azil în Italia şi aveau relaţii foarte proaste cu statul român.

MC: Să înţeleg că dumneavoastră, din ţară, nu aţi primit niciun dosar cu documente, absolut nimic ?

CB: Nimic! Nimic absolut!

MC: Doar povestea ...

CB: Am început tratativele fără să am nici cel mai mic document, nici din trecut, nici din prezent, doar dorinţa de a obţine copia Columnei lui Traian. Şi în 1966, în iulie, am început tratativele cu Vaticanul prin nunţiul apostolic Carlo Grano ${ }^{5}$. Tratativele propriu-zise le-am purtat cu monseniorul Agostino Casaroli ${ }^{6}$, cardinal care îndeplinea funcţia echivalentă cu ministru de externe şi prim-ministru. Era „mâna dreaptă” în relaţiile Vaticanului cu alte state.

MC: Cum aţi ajuns să-l contactaţi pe nunţiul papal Carlo Grano? Inţeleg că Domnia Sa va înlesnit apoi contactele cu cardinalul Casaroli.

CB: Am numit în cadrul ambasadei un diplomat pentru legăturile cu Vaticanul şi l-am trimis pur şi simplu la Nunţiatura Apostolică cu mesaj din partea mea către nunţiul apostolic că doresc o întâlnire cu Domnia Sa. S-a fixat întâlnirea. I-am expus scopul întâlnirii, respectiv copia Columnei lui Traian, a notat ceva, nu a făcut nicio declaraţie, pentru că, sigur, avea nevoie de instrucţiuni.

MC: Aşa cum spuneţi dumneavoastră pare foarte simplu; eu v-am întrebat pentru că relaţiile României atunci cu Papalitatea nu erau tocmai cordiale ...

CB: Nu! Dar eu, ca ambasador, să vă spun cinstit, nu vreau să mă laud, dar eram în relaţii foarte bune cu toţi. Nu ţineam seama că statul român nu are relaţii cu nu ştiu ce stat, nu ţineam seama că noi eram reprezentanţi oficiali din partea unui stat comunist şi discutam cu democratcreştinii italieni, adică, eu, ca ambasador, eram egal cu toată lumea. Îl cunoscusem pe nunţiul

\footnotetext{
${ }^{3}$ Accademia di Romania a Roma (Şcoala Română din Roma) - instituţie ştiinţifică şi culturală înfiinţată la propunerea lui Nicolae Iorga şi Vasile Pârvan destinată perfecţionării tinerilor licenţiaţi români în domeniile ştiinţelor umaniste, al artelor plastice şi arhitecturii.

${ }^{4}$ Maria Sofia Panaitescu, n. Lahovary (d. în 1997 în SUA, la Calaveras, California)

${ }^{5}$ Carlo Grano (14 octombrie 1887, Roma - 2 aprilie 1976, Roma) - din 13 decembrie 1958 nunţiu apostolic în Italia şi arhiepiscop titular de Salonic. Numit cardinal în ziua de 26 iunie 1967.

${ }^{6}$ Agostino Casaroli (24 noiembrie 1914 - 9 iunie 1998) - în 1961 intră în Secretariatul de Stat al Vaticanului. Diplomat, este cel ce tratează cu regimurile ostile Bisericii Catolice, încheind acorduri cu Ungaria, în anul 1964, şi Iugoslavia, în anul 1966. Arhiepiscop de Cartagina din data de 16 iulie 1967. Între 29 aprilie 1979-1990 a îndeplinit funcţia de secretar de stat (prim ministru) al Sfầntului Scaun. El este cel ce a prezidat Conferinţa pentru Securitate şi Cooperare în Europa de la Helsinki, în 1975.
} 
apostolic la nişte manifestări diplomatice, dădusem mâna, ne recomandasem, între noi existau nişte relaţii normale, care ulterior s-au transformat în relaţii de prietenie. Nunţiul papal a venit şi cu un diplomat al lor, actualul cardinal Luigi Poggi ${ }^{7}$, care la vremea respectivă era un simplu ataşat.

GT: Sunt 40 de ani de atunci ...

CB: Acum m-am bucurat mult când am auzit că a fost numit deja cardinal ... La următoarea întâlnire am avut plăcerea să mă văd cu cardinalul Casaroli la Grottaferrata, aşa mia propus. Ne-am văzut acolo într-o ambianţă foarte plăcută. Era un restaurant, aşa, mai select, pentru astfel de discuţii discrete. La prima întâlnire, Casaroli mi-a propus să purtăm discuţii pe toate problemele existente la vremea respectivă între Vatican şi România, inclusiv diocezele grecocatolice, situaţia unor clerici - unii dintre clerici aveau domiciliu obligatoriu - in fine, erau multe incurcături cu biserica care depindea de Vatican. Eu am spus că nu am mandat din partea României pentru astfel de discuţii. Deocamdată, am mandat pentru acest subiect concret, care era copia Columnei lui Traian. I-am prezentat istoricul copiei Columnei lui Traian şi am stabilit că problemele ,încurcate” dintre noi să le lăsăm pentru mai târziu, să lăsăm lucrurile să decurgă normal, fără să le forţăm. Cunoşteam care era poziţia alor noştri din conducere la vremea respectivă; mai ales (Emil) Bodnăraşs se împotrivea categoric unor normalizări ale relaţiilor cu Vaticanul. Am început tratativele în iulie. Pe urmă în luna august, când la dânşii e o lună a concediilor, am mai schimbat diverse argumente, au mai venit cereri concrete din partea lor, eu leam dat răspunsul ...

MC: Ca de exemplu, ce înseamnă cereri concrete?

CB: De exemplu, era un Monsenior, nu îmi mai aduc aminte, şeful Bisericii greco-catolice la vremea respectivă ...

MC: Iuliu Hossu ${ }^{9}$, la Căldăruşani ...

CB: Exact! Avea domiciliu forţat şi el nu primise aprobare să meargă în Italia să fie uns cardinal ... Unele le-am mai rezolvat, altele au rămas ,agăţate”. În orice caz, eu am insistat tot timpul pe faptul că „, haideţi să facem un prim gest cu copia Columnei lui Traian şi apoi vom merge punctual, problemă cu problemă, până la o normalizare a acestor relaţii”. Vreau să spun că în aceste tratative am avut un sprijin extraordinar din partea Papei Paul al VI-lea, care şi-a amintit că era subsecretar de stat în perioada când a fost comandată şi executată copia Columnei lui Traian şi a spus: „Da, într-adevăr, îmi amintesc, a fost plătită!” Asta mi-a dat mie curaj şi mai mare, pentru că tot timpul mi-a fost teamă că voi fi intrebat care sunt documentele pe baza cărora facem această cerere.

MC: Într-un fel vă legitima cererea!

CB: Vă spun, nu aveam nici un fel de document, nimic, nimic absolut! Nici din ţară nu mia dat cineva vreun document, nici acolo nu am găsit. In noiembrie 1966, Papa mi-a dat, cum se spune binecuvântarea, şi a spus: „Să fie retrocedată guvernului român!” E adevărat că noi am făcut un gest în octombrie 1966, şi anume am oficializat discuţiile dintre ambasadorul României şi reprezentanţii Vaticanului, adică am trimis o notă verbală Nunţiaturii Apostolice în care am declarat că aceste convorbiri sunt convorbiri oficiale. Până atunci noi declarasem că aceste convorbiri sunt din partea Academiei Române de la Bucureşti și Vatican.

MC: În plan politic, mai precis, ce înseamnă această oficializare?

CB: În plan politic înseamnă că de fapt recunoaştem autoritatea şi statalitatea Vaticanului. Sigur că reprezentanţii Vaticanului şi Papa, ca nişte foarte fini observatori şi cunoscători ai subtilităţilor diplomatice, au apreciat foarte mult. Ei au spus: este un gest din

\footnotetext{
${ }^{7}$ Luigi Poggi (25 noiembrie 1917 - 4 mai 2010) - numit delegat apostolic în Africa Centrală pe 3 aprilie 1965, iar pe 9 mai devine episcop. Pe 21 mai 1969 este numit nunţiu apostolic în Peru, iar în august 1973 efectuează o misiune specială pe lângă bisericile din țările comuniste, inclusiv România. În anul 1975 era delegat apostolic în Polonia, iar în anul 1986 nunţiu apostolic în Italia. Pe 26 noiembrie 1994 a fost numit cardinal.

${ }^{8}$ Emil Bodnăraş (10 februarie 1904, Iaslovăţ - 24 ianuarie 1976, Bucureşti) - a fost un lider comunist român, general al Armatei Române și spion sovietic.

${ }^{9}$ Iuliu Hossu (30 ianuarie 1885, Milaş - 28 mai 1970, Bucureşti) - a fost episcop al Episcopiei greco-catolice de ClujGherla, deținut politic, cardinal, membru de onoare (din anul 1945) al Academiei Române. La 28 aprilie 1969, a fost numit cardinal in pectore de către Papa Paul al VI-lea.
} 
partea unei ţări comuniste ortodoxe de foarte mare importanţă. Şi atunci Papa, după nota noastră verbală, în noiembrie 1966, a dat verdictul - „Da! Să se dea copia Columnei!” Şi sigur, pe urmă, au început operațiunile de aducere ... Acum, aş putea spune că este cu suişuri şi coborâş̧uri.

GT: Erau ţinute în condiţii bune aceste copii ale Columnei?

CB: Sigur că da, excepţionale! De fapt, erau ca un fel de mostre în cadrul depozitului ... nu e vorba de depozite cum le ştim noi, cu tot felul de materiale. In depozitele acestea erau bunuri culturale, toate păstrate ca şi cum ar fi fost într-o expoziţie permanentă. Aşa erau şi copiile!

GT: Puteau fi vizitate?

CB: Cine dorea putea să le viziteze, sigur că da ... Nu aveau programul unui muzeu obişnuit, erau vizitate în special de către cei care erau interesaţi. Au început discuţiile cu ai noştri penrtru că eu am dat sfoară în ţară şi am anunţat să se facă o comisie a Academiei cu specialişsti în istorie şi cultură să vină să o ia, să o şi recunoască, pentru că, sigur, eu văzusem acolo nişte exponate, dar nu sunt istoric ca să pot să îmi dau seama, dacă sunt toate sau nu, succesiunea scenelor ... şi aşa mai departe. Dar, cum stau lucrurile la români, începuseră să se certe între dânşii.

GT: Muzeul Naţional nu exista încă ...

CB: Nu era! Au inceput să se certe, ,să vină Vătăşanu ${ }^{10}$, să vină Daicoviciu ${ }^{11}$ !” Au durat discuţiile acestea aproape toată luna noiembrie şi jumătate din decembrie. Cea mai mare discuţie cu ai noştri a fost în legătură cu transportul copiei la Bucureşti. Ai noştri au venit cu ideea să trimită ei nişte tâmplari, cu cuie, cu scânduri, cu tot ce vrei. Eu le-am spus: „Domnule, nu se poate, e vorba de vize, de cazare. Plus că este o adevărată artă să ambalezi asemenea valori”. Vaticanul avea o firmă care se ocupa cu aşa ceva. Am făcut o socoteală inginereşte - eu fiind inginer - şi am zis: cât mă costă dacă vin ai noştri? Erau sume mari. Cât mă costă dacă angajez firma asta? Obţineam o sumă mult mai mică. Atunci am propus să se angajeze o firmă locală pentru ambalare, pentru transport. Nu m-am putut înţelege cu ai noştri. Atunci m-am urcat în avion şi am venit la Bucureşti şi am „aterizat” la preşedintele Consiliului de Miniştri, Ion Gheorghe Maurer ${ }^{12}$, căruia i-am explicat cum stă problema. Maurer a fost de acord cu mine şi a zis: „Trebuie să vorbesc şi eu cu Ceauşescu”. Ceauşescu era la Braşov. M-am dus la Braşov. Maurer era la telefon şi a spus: „Eu sunt de părerea lui, aşa că te rog aprobă treaba asta”. I-am spus lui Ceauşescu, am făcut şi calcule. A zis: „De acord cu propunerea ta” ... şi aşa s-a făcut contractul cu firma italiană. Copia Columnei a plecat în ianuarie 1967 cu un tren cu 18 vagoane şi eu, ca să fiu sigur că ajunge în ţară, am suit consulul pe locomotivă să însotească transportul până în ţară ... A venit până la Timişoara.

MC: Au fost vagoane româneşti?

CB: $N u$, italieneşti ... pe căile ferate din toată lumea sunt anumite înţelegeri în legătură cu transportul de vagoane. Numai că la Bucureşti, altă bucurie! Au stat până în toamna lui '67 în triaj! Ministerul Culturii le-a uitat pur şi simplu ... Am venit în concediu în 1967 şi, bineînţeles, primul lucru a fost să mă interesez ce-i cu copia ... Nu ştia nimeni şi cei de la Calea Ferată mi-au spus că este un tren acolo, venit de nu ştiu câtă vreme... Atunci i-am spus lui Nicolae Ceauşescu care este situaţia ... A fost ,furtună”! ... Nu găseau loc să o depoziteze ...

GT: A fost în custodia Muzeului Satului şi apoi în custodia Muzeului Partidului. Cum a ajuns acolo?

CB: Au fost duse acolo pentru că nu aveau unde să le monteze, să le instaleze şi s-a stabilit că până se amenajează Muzeul de Istorie Naţională, să fie pur şi simplu depozitate acolo. Ce se întâmplă? Întâi au fost date spre păstrare Ministerului Culturii, s-a văzut că Ministerul Culturii nu

\footnotetext{
${ }^{10}$ Virgil Vătăşianu (21 martie 1902, Sibiu - 15 noiembrie 1993, Cluj) - istoric de artă, medievist. Între anii 1930-1931, 1934-1936 şi 1938-1940 a fost secretarul Şcolii Române de la Roma. Revenit în ţară, devine titularul catedrei de Istoria Artei la Universitatea din Cluj.

${ }^{11}$ Constantin Daicoviciu (1 martie 1898, Căvăran - 27 mai 1973, Cluj) - profesor la Universitatea din Cluj între anii 1923-1968, iar între 1957-1968 şi rector. Din anul 1945 până în 1973 director al Muzeului de Istorie al Transilvaniei. Membru al Academiei Române, din anul 1955. Din anul 1961 membru al Consiliului de Stat. În perioada 1925-1927 a fost bursier al Şcolii Române de la Roma.

${ }^{12}$ Ion Gheorghe Maurer (23 septembrie 1902, Bucureşti - 8 februarie 2000, Bucureşti) - prim ministru în perioada 1961-1974.
} 
prea avea treabă cu asta şi atunci s-a luat hotărârea să fie dată la Muzeul de Istorie Naţională şi expuse nu numai pentru studiu, dar şi pentru vizitare.

Acum vreau să vă spun că noi nu am fost prea corecţi cu Vaticanul, pentru că Papa ne-a dat copia Columnei, dar ne-a rugat un singur lucru.

MC: Chiar vroiam să vă întreb.

CB: A renunţat la toate pretenţiile cu care venise şi a zis doar atâta: „Vă rog ca atunci când se va inaugura copia Columnei la Muzeul de Istorie Naţională, în cuvântul celui ce va rosti discursul să se spună o frază, că această copie a fost găzduită timp de 30 de ani de către Vatican”. Nici măcar treaba asta nu s-a făcut ...

MC: De ce credeţi că nu s-a făcut? Neglijenţă pur şi simplu sau deranja pe cineva ...

CB: Părerea mea este că la conducătorii noştri de atunci nu prea exista simţul onoarei. Să ştiţi că e un lucru mare să fii om de onoare! Ai promis ceva şi eu am promis. Dar nu s-a respectat

MC: Deci Vaticanul a renunţat la absolut tot!

CB: Absolut tot.

MC: De ce credeţi că a renunţat?

CB: Vaticanul a dus totdeauna o politică de lungă perspectivă ... Aş putea spune că Vaticanul are filosofia chinezilor, adică nu contează un an, doi, trei, cinci ... judecă cu bătaie lungă. Şi aşa a judecat şi cu noi! Sigur să eu i-am alimentat puţin pentru că am spus: „Domnule, de ce nu vreţi să lăsaţi puţin să se sedimenteze aceste fapte pozitive şi ca un bulgăre de zăpadă, încet, încet să se rezolve şi altele, în timp ..." De altfel, vreau să spun că Vaticanul a venit, prin instituţiile sale financiare, cu o propunere extraordinară, şi anume, ne-a propus un credit de 500 milioane de dolari pentru construcţia unei autostrăzi de la intrarea în ţară, la Timişoara, până la Constanţa, cu sisteme de servicii cum sunt în Italia, cu staţii de benzină Agip de o parte şi de alta. Era un lucru extraordinar! Noi trebuia să plătim din veniturile pe care le va aduce acea autostradă. Propunerea a fost făcută prin directorul unei bănci controlate de Vatican. Ceauşescu a fost de acord, dar s-au pus alţii, tot din conducere, că ne îndatorăm la Vatican, că Vaticanul e aşa şi aşa ...

MC: In ce an a fost făcută propunerea?

CB: Propunerea a fost fãcută în '67.

MC: Deci în perioada în care Ceauşescu nu-şi consolidase încă puterea, depindea şi de ceilalţi ...

CB: ... Şi aşa s-a ajuns până la urmă cu copia Columnei lui Traian unde trebuie. Acum să vă spun drept, pe mine m-a deranjat o afirmaţie a unui fost ministru de externe, Mănescu ${ }^{13}$, care, într-o discuţie cu (Lavinia) Betea, afirmă că vezi Doamne, el ar fi purtat discuţiile cu Papa şi că în '67 ... şi în '68 a fost definitivat acordul când a fost Maurer în Italia. A fost în vizită oficială ... ori Columna era deja de un an de zile aici. Dar astea sunt exagerări ...

GT: Şi transportul cine l-a plătit?

CB: Statul român, noi am plătit tot. Ba, mai spune Mănescu că Ceauşescu s-ar fi opus aducerii copiei Columnei lui Traian ... ori nu este adevărat.

GT: Deci, el v-a dat ordin să faceţi asta ...

CB: Cine? Ceauşescu, da ... Deci înainte de a pleca, Ceauşescu m-a chemat la Snagov, acolo şi mi-a pus probleme economice, probleme politice. Şi mi-a dat aceste două lucruri: Columna lui Traian şi Accademia di Romania.

GT: De unde a avut el informaţii despre ele sau ideea, nu ştiţi ... cine i-a pus-o lui?

CB: Eu cred că i-a pus pe cei de la Institutul de Istorie al Partidului ... pentru că să ştiţi, era impropriu spus Institutul de Istorie al Partidului. Ăla era de fapt institutul de cercetare istorică al lui Ceauşescu, pur şi simplu! Asştia erau cei care căutau în arhive ... aşa bănuiesc eu, că eu nu am întrebat atunci şi nici mai târziu n-am întrebat. Bănuiesc a fost semnalat de aceştia. Ii făceau tot felul de sinteze. Era generalul (Gheorghe) Zaharia; el îi scosese pe toţi cei dinainte care erau cu partidul, cu ilegalitatea şi băgase din ăş̧tia care se ţineau de istoria naţională.

\footnotetext{
${ }^{13}$ Corneliu Mănescu (6 februarie 1916, Ploieşti - 26 iunie 2000, Bucureşti) - Ministru de Externe între 21 martie 1961 23 octombrie 1972.
} 
GT: Dar la muzeu era (Ion) Ardeleanu, nu?

CB: Nu, era (Florian) Georgescu... La Muzeul Partidului era Ion Ardeleanu ${ }^{14}$, era Coroiu.

GT: Florian Georgescu ${ }^{15}$ a fost după aceea la Muzeul Naţional de Istorie ... Şi după asta

CB: Am fost Ambasador între anii '66-69, trei ani şi după aia am fost numit ministru al Comerţului Exterior.

MC: Domnule Burtică aţi spus că aţi avut două probleme: copia Columnei şi Accademia di Romania. Aţi precizat retrocedarea, şi apoi v-aţi corectat singur, recuperarea Accademiei di Romania. Cele două cuvinte, cele două noţiuni, spun ceva despre statutul Accademiei din Romania din acel moment.

CB: Să vă spun cum e cu Accademia di Romania ... Statul italian, de fapt primăria Romei a oferit tuturor statelor care au dorit să-şi facă lăcaşe de cultură pe care le numesc Accademia, teren ca să-şi construiască cu mijloace proprii. Accademia di Romania, Accademia Egiptului, Accademia nu ştiu cărui stat ... Statul român a construit aceasta prin 1923-1924 $4^{16}$.

GT: $\mathrm{Cu}$ Iorga ...

CB: Iorga, Pârvan ... era pe vremea fascismului, dar era un fascism mai socialist. $\hat{I} n$ statutul acesteia era obligaţia ca întreţinerea să o plătească statul român, iar a doua obligaţie era că nu se admitea schimbarea obiectului de activitate, adică era numai de activităţi culturale şi de invățământ. Erau spaţii de cazare pentru bursieri, bursieri de invăţământ, bursieri de pictură, sculptură, ş.a.m.d. Şi, de asemenea, nu era admis să nu aibă activitate, adică să fie pasiv. Totul a mers destul de bine până după al Doilea Război când autorităţile de atunci au spus: „Ce lege internaţională, ce inţelegere cu italienii ... e a noastră, mutăm în ea Ambasada şi Agenția Română". I-au schimbat obiectul de activitate! Statul italian, mai ales că erau şi relaţiile încordate în Războiul Rece, a pus poliția pe noi şi ne-au evacuat din clădire. Au închis clădirea, au pus scânduri la ferestre şi la uşi şi ne-au obligat să punem un paznic. Şi toată treaba asta a durat până în 1966. In baza sarcinii date de şeful statului, mi-am permis să o vizitez. Am cerut permisiunea Statului Italian să o vizitez. Ei, vă dati seama, era într-o stare jalnică, era praful de $30 \mathrm{~cm}$, mergeai cu picioarele prin praf, parcă erai în Sahara. Am început convorbirile cu Ministerul de Externe italian şi anume cu directorul general Gaia. Acest director general la ei este mai important decât un ministru adjunct la noi, e aproape ca şi ministrul. El deţine în mână toate relaţiile publice cu statele lumii. Discuţiile au fost destul de grele la început pentru că, deşi în statutul Accademiei nu se prevede că $\hat{\imath} i$ dai altceva în schimb italianului ca să-ţi dea Accademia, italienii totuşi, prevalându-se de faptul că statul român naţionalizase o seamă de clădiri culturale ale italienilor de la Constanţa şi Bucureşti, au spus: „Domnule, vă cedăm doar dacă ne daţi şi nouă altceva în loc”. Bineînţeles că Accademia noastră este foarte frumoasă, e mare, spaţioasă. Vă închipuiţi ce ar fi însemnat să dăm ceva în loc! Convorbirile cu italienii au durat câteva luni de zile până am ajuns la o înţelegere şi anume, să le dăm măcar un club, un club cultural. Am venit în Bucureşti să căutăm un club. Am dat de un club al sindicatelor sanitare, pe strada Nuferilor, cum îi spunea pe vremuri ${ }^{17}$... Şi am găsit acolo un spaţiu cu vreo cinci camere. Destul de frumos, arătos ...

\footnotetext{
${ }^{14}$ Ion Ardeleanu a fost director adjunct al Muzeului Partidului din 1965 până în 1989. În perioada 1968-1971 a răspuns de organizarea Muzeului de Istorie al României.

${ }^{15}$ Florian Georgescu (19 noiembrie 1924 - 15 mai 1997) - a fost director al Muzeului de Istorie al României în perioada 1971-1984.

16 Înainte de Primul Război Mondial, prin 1914, Vasile Pârvan şi Duiliu Zamfirescu lansau ideea înfiinţării unei „Şcoli româneşti la Roma". Abia după război, în 1920, Nicolae Iorga cu mai mulţi parlamentari, reiau ideea prin înfiinţarea a două şcoli româneşti - la Paris şi Roma. În anul 1921 Consiliul de Miniştri aprobă Regulamentul de funcţionare, iar pe 1 noiembrie 1922, sub conducerea lui Vasile Pârvan, Şcoala Română din Roma îşi începe oficial activitatea, într-un local închiriat. În urma concesionării unei suprafețe de 50.000 m.p. în parcul Valle Giulia, Villa Borghese, cu sprijinul financiar al Băncii Naţionale a României, se ridică impunătoarea clădire a Accademiei di Romania. Planurile i se datorează arhitectului Petre Antonescu. La 27 ianuarie 1928, în prezenţa lui Nicolae Titulescu, se pune piatra de fundație, iar inaugurarea are loc în ziua de 10 ianuarie 1933. În timpul celui de al Doilea Război Mondial funcţionează cu un personal foarte redus, iar în anul 1947 este închisă. Din anul 1948 până în 1969 este practic abandonată. Revine statului român în 1969, dar funcționează ca centru cultural abia din 1990.

${ }^{17}$ Fosta şi actuala stradă general Henri Mathias Berthelot (n. 7 decembrie 1861 la Feurs, Franța - d. 28 ianuarie 1931) general al armatei franceze, participant la Primul Război Mondial pe frontul din România ca şef al Misiunii Militare Franceze.
} 
MC: Pe colt cu strada Spiru Haret.

GT: Da, care era Casa Teatrelor Naţionale şi Operelor Naţionale ...

CB: Nu mai ştiu ... I-am întrebat pe italieni, iar ei au fost de acord cu acest spaţiu. Şi neam înţeles să închidem acest litigiu printr-un schimb de scrisori între miniştrii de externe. Am acţionat şi la Externe şi la conducerea deasupra Externelor ca să obţinem banii să reparăm toată clădirea asta de la Roma.

MC: Cum aţi făcut reparaţia, cu meşteri din ţară sau cu meşteri italieni?

CB: Nu, am adus din ţară şi să vă spun de ce ... Noi am şi schimbat puţin construcţia pentru că făcuseră sala de festivităţi sau mă rog sala de conferinţe, fără intrare din interior şi trebuia să ieşi afară ca să intri în sala de conferinţe. Atunci am chemat oamenii noştri, am făcut spărturi ca să facem legătura dintre spaţiile interioare şi ... că asta era şi sală de expoziţie, sală de conferințe, sală de diverse activităţi, şi am făcut-o funcţională pe de o parte ... Pe urmă le-am reparat italienilor aici, ca să dăm totuşi sala aşa cum trebuie ... Am elaborat şi scrisoarea. În 1967 a venit în vizită în România Amintore Fanfani ${ }^{18}$ - ministrul de externe - şi atunci urma să facă schimb de scrisori cu Mănescu. Numai că în timpul convorbirilor cu Mănescu i s-a făcut rău, cu stomacul lui şi deodată s-a enervat, aşa din senin şi mai, mai să se întrerupă relaţiile, convorbirile dintre ei ... Eu, ca ambasador, făceam naveta între cei doi ca să-i împac. În sfârşit, i-am împăcat, $s$-au terminat bine convorbirile, dar au uitat să semneze scrisoarea. Fanfani plecase spre Bulgaria, şi plecase cu maşinile către Ruse. Când am văzut că nu a semnat scrisoarea am pus poliţia pe urmele lor şi ne-am întors pe urmă la ambasada italiană, unde s-a semnat scrisoarea. Când am văzut că a semnat-o nu am mai dat-o la nimeni, am luat-o în mână şi am dus-o la arhivă, la Ministerul de Externe, să nu o mai piardă cineva şi să nu avem documente de retrocedare ... Aşa sa ajuns până la urmă să facem această Accademie care, sigur, în prima etapă cred că nu a fost ea aşa prea bogată în activităţi, dar depinde foarte mult de directori, ăsta este adevărul.

MC: Intotdeauna omul contează.

CB: Sigur că da. De exemplu, ştiu că atunci când a fost doamna Zoe (Dumitrescu)Buşulenga director, a fost o activitate şi de conţinut şi de suprafată şi relaţiile cu oamenii de cultură au fost altele. Astea sunt cele două - să zic aşa-obiective concrete.

MC: Pe care dumneavoastră a trebuit să le îndepliniţi. Mai am o întrebare paranteză la ceea ce aţi spus şi pe urmă o întrebare, să spun aşa, majoră ...

CB: Staţi aşa, nu am răspuns la întrebarea aceea cu retrocedarea sau cu recuperarea. Acum să vă spun de ce. Pentru că de fapt e şi una şi alta. Pentru că italienii au pus stăpânire pe ea, acesta e adevărul. Şi cealaltă e că de fapt nu prea aveau ei dreptul chiar să ne-o confiște. Da', a fost aşa, o treabă amestecată şi a trebuit să o şi retrocedeze, să o şi ,,recuperăm”.

GT: Da, atunci ştiu că s-a reparat în Bucureşti, s-a restaurat ... ei aveau un consulat pe (strada) Ion Mincu pe unde rămăsese emblema, stema Italiei cu vulturul fascist... Ţin minte copil fiind, era Biserica Italiană, care a fost mult timp închisă şi atunci s-a redeschis. Şcoala italiană era pe (strada Luigi) Cazzavillan (colt cu strada Transilvaniei) ...

CB: Eu am făcut un raport atunci şi am vorbit cu Ceauşescu următorul lucru: dacă noi vrem în mod real să dezvoltăm relaţiile cu Italia, noi trebuie totuşi să reparăm o seamă de lucruri pe care noi le-am stricat în relatiile cu ei ...

GT: Era şi Casa de la Veneţia.

CB: Da, era... Să ştiţi că autorităţile au fost de acord cu noi să o cedeze, dar aveam chiriaşi în ea; se mutaseră ilegal o seamă de cetățeni italieni care, pur şi simplu, s-au instalat în casă ... casă părăsită de 10 ani. Ai noştri din ţară nu au vrut să dea bani să facem reparațiile şi să le găsim ălora spaţii că şi la ei era cam cum era la noi: ca să dai afară chiriaşii trebuie să le găseşti undeva unde să locuiască. Din cauza asta, era a doua etapă dacă mai rămâneam ca ambasador să o rezolv. După aia s-a rezolvat, pe urmă ...

\footnotetext{
${ }^{18}$ Amintore Fanfani (6 februarie 1908 - 20 noiembrie 1999) a fost un politician creştin-democrat italian. A fost PrimMinistrul Italiei în perioadele 1954 (21 de zile), 1958-1959, 1960-1963, 1982-1983 și 1987. În mai multe rânduri ministru de Externe, de Interne, al Agriculturii etc.
} 
MC: Aţi spus că în octombrie 1966 au fost oficializate discuţiile dintre Ambasada României şi Vatican, lucru foarte important din punct de vedere politic. Ştiţi cumva care era situaţia acestor relaţii dintre statele socialiste şi Vatican la acel moment?

CB: $N u$, nu existau deci. Iar eu am mai făcut următorul lucru ca ambasador: am aranjat în ianuarie 1968, când a făcut o vizită în Italia preşedintele Consiliului de Miniştri, Maurer, să fie primit de Papă.

GT: Maurer era catolic la origine!

CB: ... A fost primul şef de guvern din România după al Doilea Război Mondial primit de Papă. L-am însoţit şi eu şi vreau să spun că discuţia a fost deosebit de interesantă. Papa a ţinut seama de tot ceea ce depănasem eu cu reprezentanţii săi, să nu se bage brutal în problemele care ne despart. Şi într-adevăr aşa a făcut. Au discutat problema cu Vietnamul care era la ordinea zilei, şi doar în treacăt... ,vom găsi, sau vor veni timpuri când să rezolvăm toate problemele existente între noi" ... La plecare şi Maurer a răspuns la fel de conciliant, în sensul că şi noi vrem să mergem spre o asemenea normalizare.

GT: Da, că Maurer a fost la de Gaulle când a stat aproape o oră în discuţii ...

CB: Da, tot eu am fost acolo ...

MC: Aţi avut ca ambasador o mulţime de contacte cu oficialităţile italiene, cu oficialităţile Vaticanului, dar, printre sarcinile primite sau pe care vi le-aţi asumat de unul singur, s-au numărat şi relaţiile cu ceea ce numim astăzi diaspora românească. Aţi avut legături cu români în Italia?

CB: Sigur că da. Şi am avut legături chiar foarte bune.

MC: $O$ sarcină dată din ţară?

CB: $N u$, nu era, cum să vă spun eu dumneavoastră, o componentă a politicii externe româneşti.

MC: Cu instrucţiuni precise? Eu insist.

CB: Da, în sensul că la toate manifestările noastre eu invitam şi reprezentanţii diasporei româneşti. De exemplu, 23 august sau ştiu eu ce alte manifestări culturale pe care le organizam, veneau. Iar la 23 august vreau să vă spun că ai noştri ştiau mai bine decât noi că trebuie să dăm recepție.

MC: Ne puteţi spune câteva nume de români cu care aţi avut contact?

CB: Da sigur că da. Eu am avut cu Drăgan ${ }^{19}$.

GT: El, pe urmă (în 1976) la Congresul de Tracologie a venit aici.

CB: El era unul dintre reprezentanţii de frunte, aşa, ai românilor. Nu prea era el agreat de ceilalți români, nu ştiu, auzisem ceva cu legionarii sau mâncase banii ... ceva în genul ăsta nu mai ştiu ...

MC: Mai trăieş̧te încă şi astăzi.

CB: Da, mi se pare că da. Dumnealui m-a rugat să îl introduc şi la Vaticam. Şi i-am făcut cunoştinţă cu Casaroli şi cu ăş̧tia ...

GT: El a avut legături şi cu Patriarhia din Constantinopol, era Mare Spătar.

CB: Ca să intru în detalii ... El de fapt avea afacerile lui cele mai profitabile în Grecia. Acolo avea el cu Butan Gazul. Şi deşi nu era ortodox, el era greco-catolic ... Acum să vă spun drept, nu prea îi mai ţin eu minte ...

GT: $\mathrm{Cu}$ Adameşteanu?

CB: Da, cu Adameşteanu ${ }^{20}$, cu Neguţescu care era un fel de poet, dar mai ales era ... un fel de pictor ...

GT: Drăguţescu!

CB: Drăguţescu ${ }^{21}$, da, era grafician, exact! Adameşteanu, la fel, era arheolog în Sicilia, ştiu că făcea săpături ... am şi fost acolo când făcea el săpături.

\footnotetext{
${ }^{19}$ Iosif Constantin Drăgan (20 iunie 1917, Lugoj - 21 august 2008) - om de afaceri stabilit în Italia în 1940, în urma unei burse acordate de Institutul Italian de Cultură. Este atras de idealurile Gărzii de Fier, el având opinii corporatiste. În 1941 coordonează o companie ce exportă petrol românesc în Italia, iar în 1948 compania Butan Gas. După 1969, prin idei protocroniste şi naţionaliste, devine colaborator semioficial al regimului lui Ceauşescu.

${ }^{20}$ Dinu Adameşteanu (25 martie 1912, Toporu, Vlaşca - 21 ianuarie 2004, Italia) - profesor la Universitatea din Lecce şi director al Şcolii de Specializare în Arheologie Clasică şi Medievală.

${ }^{21}$ Eugen Drăguţescu (19 mai 1914, Iaşi - 1993, Roma) - artist plastic român stabilit în Italia.
} 
GT: Din păcate a murit de curând.

CB: Da, de curând, am auzit şi eu. Althii, mai de vârf, nu. În rest aveam scandaluri, să vă spun cinstit. Veneau italieni în România, găseau câte o fufă din asta pe aici şi pe urmă ajungeau la scandal pentru că româncele când ajungeau în Italia se uitau şi la alţii ... Şi veneau la ambasadă pe urmă să îmi spună mie să îi iau paşaportul româncei pentru că asta nu mai merită să stea în Italia ... Cum să i-l iau?

MC: Ar mai fi ceva de spus şi nu v-am întrebat eu? Referitor la aceste teme că aşa multe ar mai fi de spus...

GT: Eu nu mai ţin minte fiindcă în 1967, când a venit Columna, eu tocmai terminasem facultatea. Când s-a deschis la Muzeul Partidului, ea acolo a fost expusăa, ştiu că s-a scris în ziare, $s$-a vorbit de deschidere, că e prezentată publicului, dar nu am fost. Doar mai târziu am văzut-o. După aceea s-a hotărât mutarea la noi, la muzeu unde a fost adusă cu camionul de la Şosea. Un camion, o metopă.

CB: Acum, să vă spun, ei au deschis-o acolo şi de gura mea, pentru că eu l-am tocat la cap pe Ceauşescu. Ca ministru al Comerţului Exterior am avut prilejul să am legături mai dese cu Ceauşescu şi de fiecare dată îi spuneam: „Domnule, chiar nu suntem capabili să facem un adăpost, ceva, să o punem undeva?" La un moment dat i-am spus facem o popicărie ...

GT: Clădirea nouă din spatele Muzeului (Partidului) nu era construită.

CB: $N u$, nu era construită.

GT: Şi acolo mult timp a fost Adamclisi. Tot monumentul de la Adamclisi a fost înainte de război dus acolo, il ţin minte, copil fiind.

CB: Da. Şi atunci i-am spus: „Găsiţi-mi un loc provizoriu, nu ştiu unde şi hai să facem totuşi Muzeul de Istorie Naţională. Toată lumea ştie, Vaticanul ne urmăreşte cu treaba asta”. Şi Ceauşescu a dat dispoziţie atunci şi au dus-o acolo, dar repet încă o dată, ca o soluţie provizorie, nu ca soluţie definitivă.

MC: Pentru astăzi vă mulţumim, dar eu nu pot să închei fără a vă solicita și alte interviuri, pe alte teme.

CB: Da, sigur, eu sunt un tip vorbăreț. 